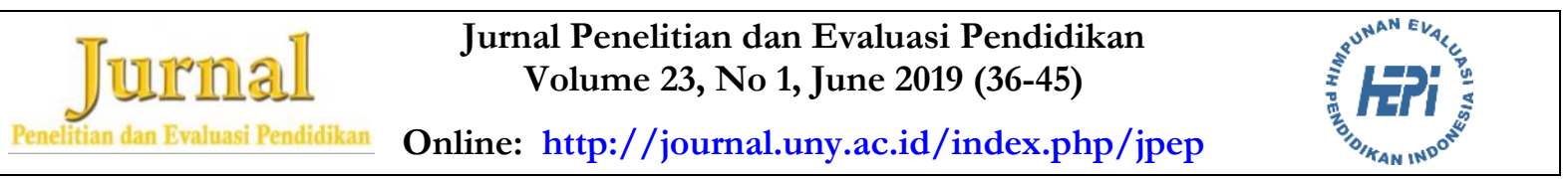

\title{
AN EDUCATIONAL-EVALUATION STUDY FOR STREET CHILDREN IN RUMAH IMPIAN FOUNDATION
}

\author{
Aulia Ninda Haryoni \\ Graduate School, Universitas Negeri Yogyakarta \\ Istiana Hermawati
}

Center for Research and Development of Social Welfare Service, Ministry of Social Affairs

\begin{abstract}
This research aims to evaluate the education of street children at Rumah Impian Foundation in Yogyakarta. This is an evaluation research using a responsive evaluation model with a naturalistic qualitative approach. The evaluation stages carried out in this study consist of Rational, Anteccendent, Transaction, and Outcome. The sampling technique used was purposive sampling with snowball sampling because the data were obtained from the community of the subjective sample, or in other words, the sample used is very rare and is grouped in a set. The data were analyzed using qualitative analysis techniques by Milles and Huberman. The results of the study show that, at the rational stage, the background of the educational concern for street children starts with a sense of caring about the street children's future that is worth fighting for. In the antecedent stage, there is a conformity input between the volunteer, apprenticeship membership, and the street children's education needs, in the form of policies and recruiting volunteers to be a companion to street children. At the transaction stage, the process between the foundation and street children education is appropriate, meaning that the foundation has facilitated the education needed by street children both formally and non-formally, in the form of increasing their skills through courses. Thus, there is a match between what was done in the previous stages and its results, showing that there are street children who reach their dreams, as a result of the foundation's efforts to continue knitting their dreams through intensive activities and assistance.
\end{abstract}

Keywords: street children, responsive evaluation, Rumah Impian Foundation

Permalink/DOI: http://dx.doi.org/10.21831/pep.v23i1.22573

\author{
Contact Aulia Ninda Haryoni \\ auliaharyoni13@gmail.com \\ Department of Educational Research and Evaluation, Graduate School of Universitas \\ Negeri Yogyakarta \\ Jalan Colombo No. 1, Karangmalang, Depok, Sleman, Yogyakarta 55281, Indonesia
}




\section{Introduction}

Education is a future investment. It is always seen as something useful for the advancement of humanity. Indeed, education is an important reference for the advancement of national civilization. The importance of education is seen as the basis for growing the future of humankind, from children to adulthood. It is, of course, inseparable from the meaning of education according to the father of education in Indonesia, that is, Ki Hadjar Dewantara, which refers to the effort to advance the character, mind, and body of the child, to advance the perfection of life, which is, living in harmony with nature and society (Neolaka \& Neolaka, 2017).

In line with the meaning of education above, education itself can be used as a foundation to obtain noble values that can make children develop according to their abilities and also the skills they should get. Education will give meaning to life for children to achieve their dreams, ideas, and hopes. Education is very broad, and can be obtained anywhere, not always obtained from the school. In practice, education has its own axiological foundation, which is described in Figure 1.

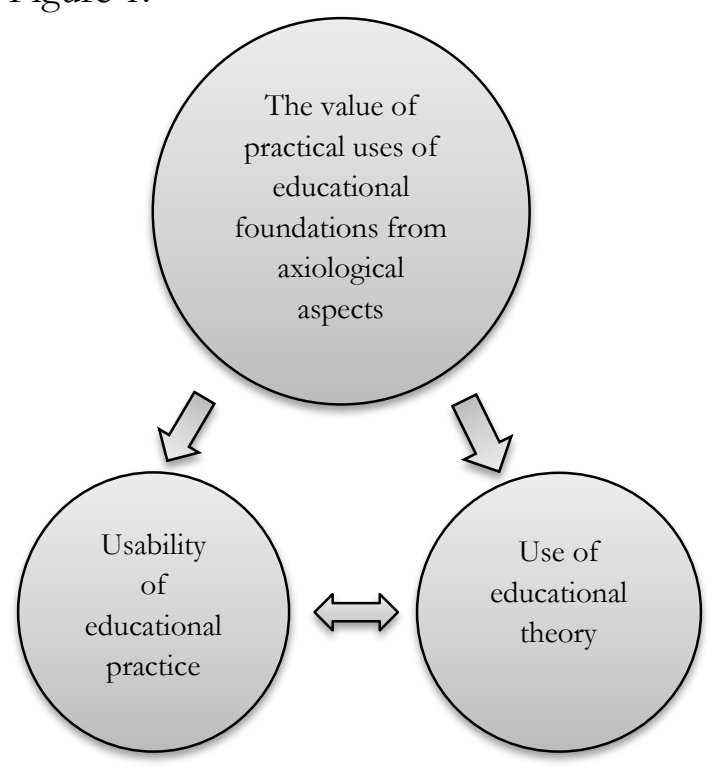

Figure 1. The Foundation of the

Educational System Axiology (Neolaka \& Neolaka, 2017)
In other words, education must be able to determine the values that will be used in the education process, both in theory and practice. The values in education will then affect how the learning process and learning atmosphere of the students themselves. As explained in the Act, education is a conscious and planned effort to create a learning atmosphere and learning process so that students actively develop their potential to possess the power of spiritually religious, selfcontrol, personality, intelligence, noble character, and the skills needed by each person and the community (Law of Republic of Indonesia No. 20 of 2003).

Departing from the educational foundation, it is known that the right to obtain education has been stated in Law No. 31 paragraph 1 which says "every citizen has the right to education" (Article 31 of the 1945 Constitution). It means that all people, including children who are Indonesian citizens, have the right to procure education. However, in reality, this is not the case. Not all citizens, especially children, get these rights, one of which is street children.

Education polemic for all cannot be felt fully by some people, especially street children. In this case, education for street children has also been regulated in the Child Protection Act, which also regulates the rights of children. Law No. 23 of 2002 concerning child protection states that a child, someone who has not reached the age of 18 years, has the right to obtain education and teaching in the context of his personal development and the level of intelligence according to his interests and talents. It is compulsory education, in which the government gives room for all children, but there is no penalty when they do not go to school, might be due to the economic problems. Then, the paragraph also explains how children have the right to obtain protection in the education unit from acts of crime and violence committed by educators, education personnel, fellow students, and or other parties, so that it can be seen that education is a right that must be given to children, including street children. 
Street children are a social phenomenon that cannot be separated from the factor of social value, which takes effect in the community. The phenomenon of street children is often triggered by economic conditions (Ray, 2017). Before discussing further in this article, street children have their own description. Not that all children who are on the streets are street children, but, deeper than that, Lusk (1992) developed four categories of children found on the road. A research conducted in 2012 in Semarang gave an explanation of the characteristics of street children, including: (1) being in public places (roads, markets, intersections, shops, and entertainment venues) for three to 24 hours per day; (2) having low education (most of them drop out of school or are too late for school age); (3) coming from families with low or poor economy condition (there are some who are not clearly family members and come from urban groups) (Rochatun, 2015).

Each group has its own psychological characteristics. Each characteristic is elaborated as follows. First, some poor children work and return to their families at night. They tend to go to school regularly and are not naughty. Second, there are some independent street workers whose family relationships are not harmonious, their school activities have decreased, and their delinquency has tended to increase. Third, there are children from street families who live and work with their families on the streets. Their condition is tied to poverty. In India, they are referred to as sidewalk dwellers (Patel, 1983), while in the United States, they are children from homeless families. And fourth, there are children who break up with their families. They are on the streets full time and are "real" street children (Aptekar \& Stoecklin, 2014).

Living as a street child does not mean that a child chooses this without any reason. Viewed from this category, the condition that causes children to be more interested in taking to the streets is the condition of their family and economy. However, it does not mean that they forget about education for themselves. Their right to get a decent life in their environmental community has also been regulated in the Law, protection of them has also been regulated in it. However, we cannot prevent children from taking to the streets just like that.

Such phenomenon of street children has developed in many regions throughout Indonesia. Big cities are the center of growth for street children, which makes their mobility very high. The existence of street children in big cities that are turning into metropolitan cities is certainly not a strange view. According to Malia (2016), 16 provinces are targeted by street children, including, North Sumatra, West Sumatra, Riau Islands, South Sumatra, Lampung, Jakarta, Banten, West Java, Central Java, Yogyakarta, East Java, East Nusa Tenggara, West Nusa Tenggara, South Kalimantan, West Kalimantan, and South Sulawesi. The data are obtained from data on the number of street children handled by the Ministry of Social Affairs of the Republic of Indonesia. Out of those provinces, Yogyakarta is one of the provinces prone to the growth of street children. The data on the number of street children in Yogyakarta handled until 2017 is presented in Table 1.

Table 1. Number of Street Children in Yogyakarta

\begin{tabular}{cc}
\hline Years & Number of Street Children \\
\hline 2013 & 212 \\
2014 & 220 \\
2015 & 219 \\
2016 & 327 \\
2017 & 348 \\
\hline
\end{tabular}

Source: (Regional Development Planning Agency, 2018)

The number of street children which tend to increase will certainly become a vital urgency to discuss. It certainly concerns the fate of education that can accommodate the collection of children. We know Yogyakarta as a city of student because many schools are growing and developing well in this city, in addition, Yogyakarta is also a destination for the wider community to take their education 
both from within or outside Yogyakarta area itself (Goenawan \& Harnoko, 1993). However, it would be ironic if education for street children was not taken into account even though Yogyakarta is one of the provinces with a steady growth in street children.

Education for street children is still seen as a formal matter, which means that when children take part in learning activities at school, they are considered to have already received education, but it cannot ascertain how they will stop taking to the streets to complain about their fate. More than that, the condition of street children is different from children in general who still have intact, caring, and always available families to take care of their development. Street children have their own views about how they live their lives and try to survive amid the difficulties of their families and economic conditions (Ray, 2017).

Treating street children is not just about sending them to the 12 -year compulsory education level, but more than that, it is about giving a value of life that is beneficial to the wider community. Of course, this is in line with the meaning and bases of education that was proposed by Ki Hadjar Dewantoro before. Education does not only come from formal schools but can also come from many sources. One of them is humanizing education like the one at Rumah Impian Foundation, Yogyakarta. Thus, this research evaluates how education for street children is carried out at the Rumah Impian Foundation and provides appropriate recommendations in order to reduce the number of street children in Yogyakarta, and broadly throughout Indonesia.

\section{Research Method}

This study is an evaluation research using a responsive evaluation model with a qualitative approach which was developed by Stake (Stake, 2005). This evaluation is called a client-centered evaluation. According to Stake, evaluation is called a response if it meets three criteria: (1) more oriented directly to program activities, than program objectives; (2) respond to the requirements of the audience's information needs; and (3) perspectives of different values from people served are reported in the success and failure of the program. This model was used because the researchers want to understand more in the activities of implementing education for street children (Stufflebeam, Madaus, \& Kellaghan, 2000). Furthermore, the information needed in this evaluation model is rational, antecedent, transaction, and outcome. Rational is intended to find out the background of the philosophy and the basic purpose of a program. The antecedent is used to see the input or initial conditions of the program. Transaction regarding the process was carried out by Rumah Impian Foundation in conducting education for street children, while the outcome explains the results of the program (Worthen \& Sanders, 1973).

The principle used in processing data from the evaluation results is the descriptive naturalistic principle by finding the contingency or possibility that can occur as well as the congruency or conformity with the expected goals. Conformity was obtained by comparing the results of interviews, study documents, and observations in the field. Data collection was done using direct observation, in-depth interviews, and document studies.

The sampling technique used in this research was purposive sampling with snowball sampling, in which the researchers interviewed the chairperson of the foundation as the primary informant, one staff member who also works at the Rumah Impian Foundation, and two street children. Besides, the researchers also examined the documents that were used as a reference for implementing the educational services program, such as the certificates of legality and letters of cooperation with other parties. The research took place at Rumah Impian Foundation Yogyakarta, located in Purwomartani, Sleman, Yogyakarta. In data analysis, the techniques used were qualitative analysis, data collection, data reduction, data presentation, and also conclusion drawing (Miles \& Huberman, 1994). 


\section{Findings and Discussion}

\section{General Description of the Location}

Rumah Impian Foundation is a nonprofit foundation that is engaged in the social sector that is concerned with the fate of street children, especially in Yogyakarta. The Rumah Impian Foundation began its approach to street children in 1999. In 1999, the Foundation had not yet been established but still as a movement to care for street children in Yogyakarta containing students who were studying in Yogyakarta and named Rumah Impian (Source: Interview data, 12 December 2018).

Developing the potential of street children is certainly not easy, so following the development, the community of the movement began to expand in 2006 and formed a foundation named Rumah Impian Foundation. The choice of the name is due to the existence of regulation from the government that the name of an established foundation must use an Indonesian-termed name, and if a foreign language is used, it must have an acronym or an abbreviation in Indonesian. In 2006, the foundation first owned a halfway house located in Jetis Yogyakarta.

In 2008 the foundation continued to grow to have several shelters to accommodate street children. In the process of its founding, many obstacles were experienced, such as rejection from the comunities at some areas in Yogyakarta. However, the Rumah Impian Foundation itself has a belief that every street child has equal rights in all fields, especially in the field of education. They have the right to reach their aspirations, and they need the right support to live an independent life in achieving their aspirations, being responsible for themselves and having a caring attitude towards others and their environment. The activities done in the foundation is presented in Figure 2.

In approaching street children, the Rumah Impian Foundation continues to develop holistic methods to assist children at risk. Funds used by the foundation in assisting the implementation of mentoring activities come from regular donors, as well as general donors spread across several regions in Indonesia. The children at risk are categorized as follows: (1) Children who cannot reach their dreams or be kept away from their dreams; (2) children living on the streets aged 0-15 years; (3) children with marginal or low income; (4) children in accordance with the age range determined by the child convention which is $0-17$ years old; and (5) children whose communities and families face the law.

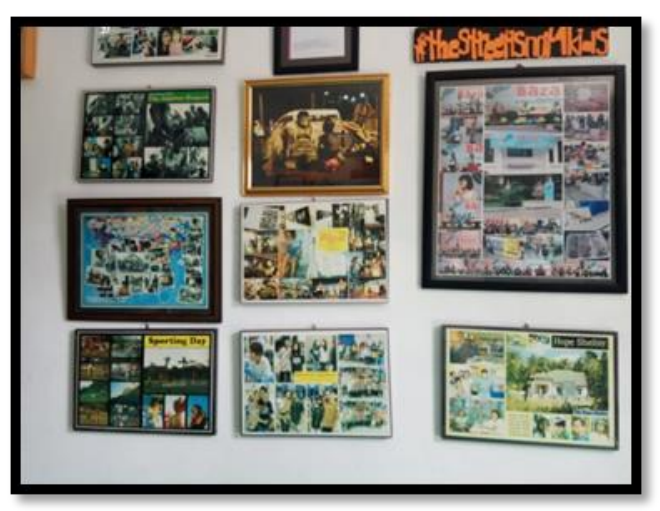

Figure 2. Documentation of the Activities of the Rumah Impian Foundation (Source: Field Documentation)

Rumah Impian Foundation has the belief that every street child has their own dreams. They are then fostered and accompanied by using a family approach so that there are no differences that can hinder their dreams.

This foundation has a vision, mission, and values that must be adhered to by street children guided by them, besides that it is also used as a companion as a stepping stone to accompany street children (see Figure 3). The vision of the Rumah Impian Foundation is "transforming the lives of children at risk through dreams that affect others" (Document study, December 2018). Meanwhile, the mission of the Rumah Impian Foundation is contained in three points: (1) accompanying children at risk as friends; (2) facilitating children at risk of realizing impactful dreams; (3) building a network to care about children's dreams. Then, for the values that exist in the Rumah Impian Foundation that they believe, (1) children have the right to dream and realize their dreams in a 
supportive community - the road is not a good place for children; (2) children need to grow into individuals who have an impact on others - the transformation of children's lives begins with dreams.

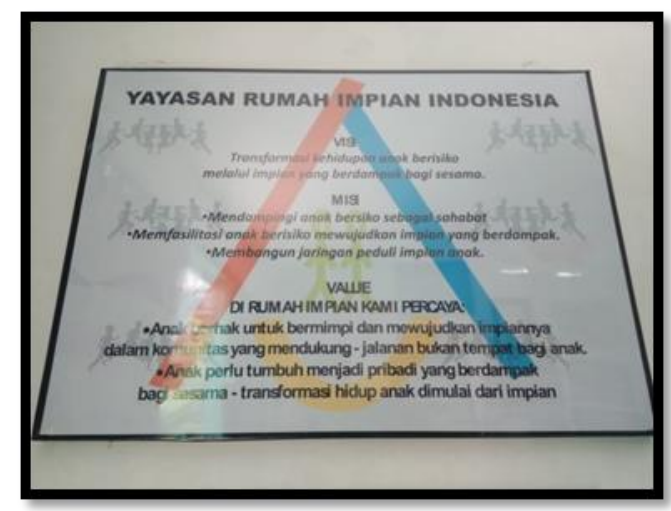

Figure 3. Vision and Mission of the Dream House Foundation. Source (Field Documentation)

Until now, the foundation continues to move and build the dreams of street children and help them to make them come true by providing many things for the street children, one of which is the Education Center program at the stage of intervention in street children. Rumah Impian Foundation believes that education is one of the rights that street children must get. Through education, they can actualize themselves into what they dream of.

The education center is a dream house built for street children (Sajiwo, 2018). The purpose of this education center is for street children so that they can actualize themselves through learning, reading, drawing, to playing, and so on. The location of the Education Center is also available in several regions, meaning that the Rumah Impian Foundation does not only have one Education Center, but they are also spread in several regions. The areas targeted by the Education Center are scattered at several points, namely Sidomulyo, Tukangan, Ngemplak, Wonocatur, and Jogoyudan (Sajiwo, 2018).

This education center program portrays how the foundation cares about education for street children. However, it is necessary to conduct an in-depth study of how education is carried out in it so that it can be known more deeply about the feasibility of the Education Center program at Rumah Impian Foundation.

\section{Evaluation of Street Children Education}

The evaluation of street children education is based on data on the number of street children in Yogyakarta in the last five years, as shown in Figure 4. Based on these data, it is necessary to conduct an initial analysis of the possible growth in the number of street children.

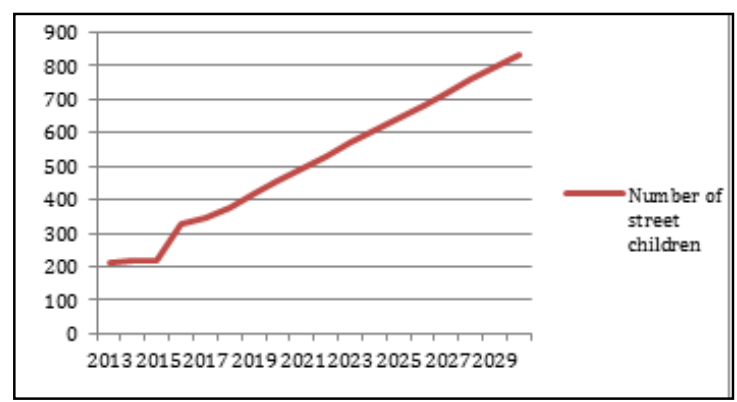

Figure 4. Projection of the Number of Street Children in Yogyakarta (Regional Development Planning Agency, 2018)

Based on the data in Figure 4, it is known that there is a significant increase in the number of street children from year to year. It can be seen from the data of the last five years, which are, of course, referred to as predictive data for the following years. The increasing number of street children is mostly caused by economic problems. Demands to fulfill life's needs make children late to experience the education that is appropriate to their age.

Street children who want to live better certainly become the main trigger in taking risky actions, namely taking to the streets. The desire to improve economic life and get money to meet daily food needs is the main thing they do. Apart from that, parents who feel less prosperous in the economy also prefer to employ their children to sing or just ask for mercy from others. On average, the street children in Yogyakarta themselves come from the Yogyakarta environment, which belongs to the marginal area. 
Apart from these increases, the program and also assistance to tackle street children are not small, many communities of observers of street children in Yogyakarta who volunteered to help them reach their dreams, of course, did not leave the realm of education. The program carried out by the Social Service itself is in the form of a program that provides services and protection for children with social problems. However, the prediction of the increasing number of street children in Yogyakarta cannot be avoided. Therefore, it is necessary to conduct an in-depth evaluation so that it is known how the Education Center program is implemented at the Rumah Impian Foundation to have an impact on street children.

\section{Rational Stage}

At this stage, the implementation of education is viewed from a philosophical aspect, namely the purpose of education for street children. The background of education for street children at the Rumah Impian Foundation itself is first seeing the enthusiasm of street children who want to achieve their dreams, but many of the street children are hit with facilities and other things that make them not have the confidence to achieve their dreams. Starting from this point, education is directed at how they achieve their dreams (Interview data, December 12, 2018). Another thing behind the implementation of education for street children is opening their dreams that were once on the road to what they dreamed of. Through the desire to make appropriate changes for street children the founders of the foundation make a breakthrough, namely to open the horizons of street children, especially in the field of education.

Then, from 2003 to 2009, the number of street children in Yogyakarta seen at intersections or major roads continued to grow from 10 to 15 children by developing the initial meeting as a transit house (Interview data, December 12, 2018). The implementation of the background is in accordance with what is in the field; the foundation has an education center which is cur- rently engaged in education for street children. Not only learning, playing, and honing skills, but more than that the foundation also facilitates and fosters them if they want to continue to a higher level of education (Interview data, 12 December 2018). From document studies, there are education center activities that are still running today and are developing by recruiting volunteers who care about street children.

\section{Antecendent Stage}

The antecedent stage is what the input is, which is the condition of the initial implementation of education for street children. This first step is to recruit volunteers who must comply with the rules or policies issued by the Rumah Impian Foundation. Recruitment of volunteers is conducted every three months, taking into account several criteria, namely: (1) must comply with child protection, because the foundation has a policy on child protection, starting from taking photos to joking with street children also regulated in this policy; (2) cooperating with several internship institutions: the Netherlands and United States of America.

Some of these volunteers were deployed directly to foster and assist street children who were also assigned to the office to create programs for street children. Then, for the financial input, the foundation is carried out using a donation system, because the foundation is engaged with the nonprofit sector so that the financial system is also limited.

From the results of the field studies and the input implementation documents, they have proceeded. Accordingly, they have recruited volunteers with due regard to the existing criteria, and then for the apprentice volunteers, they are also given the same policy that must comply with child protection. Then, the approach to street children is done by home visits and also a family approach to assisting street children to pay attention to their dreams and want to develop themselves. In addition, to ensure the safeguard rights and protections related to the personal data of street children, the foun- 
dation also applies strict things, that is, by not publishing the names of street children they are taking care of, related to their personal rights.

Assessment for children assisted by the Rumah Impian Foundation was carried out by looking at the characteristics of street children. When the research took place, the mentors who were also carrying out formal education are 120 people, and they still lived with their families. There are two places of shelter that accommodate street children for 24 hours, and three districts are available for the assisted activities, namely Yogyakarta Municipality, Bantul Regency, and Sleman Regency. This activity was also supported by street contact or outreach children directly on the road.

\section{Transaction Stage}

The transaction stage is related to the process of implementing street children education at Rumah Impian Foundation. The process for carrying out street children's education is to direct them by developing the potential that exists within them. Provide direction that education is not only obtained through formal education, but education can be obtained in many ways. Indeed, street children need to receive a formal education. This process is carried out by cooperating with various education providers, both through education, chasing packages and entering children into schools or early education institutions that work with the foundation.

For now, the facilities provided by the Rumah Impian Foundation are helping them to enter formal schools, because the school is a stepping stone to find their identity, a place in which they are trained to be able to adapt to the environment outside the street (in the sense of having friends who are not from the street environment and channeling children to outside school activities such as soccer schools and other courses). According to the foundation, to achieve the need to pass dreams, namely through bridges and bridges, the development of soft skills and formal schools is also developed.
The Rumah Impian Foundation also collaborates with the school founded by Romo Mangun. The collaboration provided includes a discount for school fees. The foundation considers that formal education is necessary for street children as a stepping stone to achieve their dreams. Then the involvement of volunteers in conducting training was also seen by the development of activities in the education center. Not only learning, but street children are also given the knowledge of other self-development such as self-actualization.

The process activities are certainly in accordance with what was done by the foundation. It was evidenced by the collaboration document between the school and the foundation, then also the schedule of learning activities at the Foundation. Also, the process of involvement of street children is starting to be active in achieving their dreams by formally attending school.

\section{Outcome Stage}

The stages of the outcome are related to the results to be achieved by the Rumah Impian Foundation, that are, the education of street children, in which street children must be able to actualize themselves, make them better and more aware to the environment. Not a few street children who continue their education to a higher level, such as entering a university with a direction they want include sports teachers, midwives, and becoming nurses, in addition to street children who attend vocational schools they choose to work directly in accordance with the majors they take.

Also, there are street children who have succeeded in becoming student council leaders in their schools, of course, this is proof that the desired expectations have been consistent with the achievement of street children's education. The number of street children carried out with assistance in formal schools amounts to 120 people who are spread throughout Yogyakarta.

The foundation issues a policy if the child can stand on their dreams; each of them will be expelled or handed over to their 
parents. Then, the foundation will issue a support system that can channel the dreams of street children into reality.

The results in the field show the compatibility between what is supposed to be and the reality. In this case, the foundation continues to develop education centers through fun learning to prevent street children from going back to the streets and also giving them opportunities to work and make a career. When the street children have succeeded in achieving what they want, the foundation does not break the relationship but builds good relations with the family; this happens in all street children assisted in the assisted locations in each district. This activity is also carried out by using an activity matrix that can be carried out and can be controlled by each activity.

\section{Conclusion}

Street children's education carried out by Rumah Impian Foundation is an education that leads to self-actualization of street children. Education is directed towards achieving the dreams they wish for.

The evaluation produces conclusions at several stages. The first is the rational stage, in which the educational background for street children emerges, namely with concern to make the founders of the foundation establish a foundation that focuses on achieving the dreams of street children and establishing an education center involving street children accompanied by volunteers. The second is antecedent stages, in which the education implementation input education input should involve education, in this case, the foundation has also involved volunteers to conduct fun-based learning activities, with the hope that street children are not quickly bored with the learning done. It is in accordance with the conditions of street children in the Rumah Impian Foundation, where, the input is made in accordance with the volunteer recruitment and also provides rules for the interests of the rights of street children fostered by the foundation. The third stage is the transaction, in which the process of education for street children should be carried out in accordance with their conditions.

The findings indicate that there is a match between what the foundation does and what it should do. The foundation facilitates street children who need education by helping them complete their vocational education courses, including those in early childhood education, and also in collaboration with schools that can facilitate formal education for street children. Then, in terms of the accuracy of the teaching process in the education center, training is also given to volunteers to foster street children according to their talents and abilities, so that it is appropriate.

The fourth stage is the outcome, in which the Rumah Impian Foundation requires street children not to go back to the street anymore, and children can succeed in actualizing themselves. In other words, it is called the termination process, carried out to foster the independence of street children, and also provide a broader life experience by providing connections to the world of work through the schools they have chosen. Data in the field shows that the foundation has carried out this termination process well, proven by the street children who had passed through the intervention process to get a better life. It is certainly in accordance with the goals of the Rumah Impian Foundation.

\section{Acknowledgment}

The authors deliver the gratitude to the Rumah Impian Foundation and the volunteers involved in it.

\section{References}

Aptekar, L., \& Stoecklin, D. (2014). Street children and homeless youth: $A$ cross-cultural perspective. Dordrecht: Springer Netherlands. https://doi.org/ 10.1007/978-94-007-7356-1

Article 31 of the 1945 Constitution of the Republic of Indonesia (1945). Republic of Indonesia. 
Goenawan, R., \& Harnoko, D. (1993). Sejarah sosial Daerah Istimewa Yogyakarta: Mobilitas sosial DI. Yogyakarta periode awal abad duapuluban. Jakarta: Direktorat Jenderal Kebudayaan.

Law No. 23 of 2002 on Child Protection (2002). Republic of Indonesia.

Law of Republic of Indonesia No. 20 of 2003 on National Education System (2003).

Lusk, M. (1992). Street children of Rio de Janeiro. International Social Work, 35(3), 293-305.

Malia, I. (2016, November 3). 16 Provinsi rawan anak jalanan. Harian Nasional. Retrieved from http://www.harnas. co/2016/11/03/16-provinsi-rawananak-jalanan

Miles, M. B., \& Huberman, A. M. (1994). Qualitative data analysis: An expanded sourcebook (2nd ed.). Thousand Oaks, CA: SAGE Publication.

Neolaka, A., \& Neolaka, G. A. (2017). Landasan pendidikan: Dasar pengenalan diri sendiri menuju perubahan bidup. Jakarta: Kencana.

Patel, A. (1983). An overview of street children in India. New York, NY: Covenant House.

Ray, S. (2017). A street child's perspective: A grounded theory study of how street children experience and cope with grief. The Qualitative Report, 22(1), 291 308.
Regional Development Planning Agency. (2018). Penyandang masalah kesejahteraan sosial dan sarana kesejahteraan sosial. Retrieved from http://bappeda.jogjaprov.go.id/datak u/data_dasar/cetak/105penyandang-masalah-kesejahteraansosial-dan-sarana-kesejahteraan-sosial

Rochatun, I. (2015). Eksploitasi anak jalanan sebagai pengemis di kawasan Simpang Lima Semarang. Journal of Unnes Civic Education, 1(1), 22-29.

Sajiwo, R. G. (2018). Model evaluasi pembelajaran sejarab: Studi kasus pada Yayasan Rumah Impian di Kalasan, Sleman Yogyakarta. Fakultas Dakwah dan Komunikasi Universitas Islam Negeri Sunan Kalijaga, Yogyakarta.

Stake, R. E. (2005). Qualitative case studies. In N. K. Denzin \& Y. S. Lincoln (Eds.), The Sage handbook of qualitative research (pp. 443-466). Thousands Oaks, CA: SAGE Publications.

Stufflebeam, D. L., Madaus, G. F., \& Kellaghan, T. (2000). Evaluation models: Viempoints on educational and human services evaluation (2nd ed.). Boston, MA: Kluwer Academic Publishers.

Worthen, B. R., \& Sanders, J. R. (1973). Educational evaluation: Theory and practice. Worthington, $\mathrm{OH}$ : Longman. 